https://doi.org/10.48009/1_iis_2010_640-643

\title{
HAS YOUR PATENT STRATEGY BEEN "BILSKIED"? CHALLENGES FACING SOFTWARE BASED BUSINESS METHOD PATENTS
}

\author{
Nancy L. Martin, Southern Illinois University, nlmartin@ siu.edu
}

David T. Green, Governors State University, d-green@govst.edu

\begin{abstract}
The popularity of patenting software has never been greater, however, recent federal court rulings (e.g., In re Bilski), strategy research, and the patent commons movement present organizations with a rather complex decision with regard to patenting their own software-based business methods. Of particular focus is the business method patent, which has been a popular yet somewhat controversial class of patents in recent years. The authors first provide an overview of business method patents, and then discuss some of the challenges facing organizational decision makers with regard to the strategic pursuit of the patent for software based business methods.
\end{abstract}

Keywords: business method patents, In re Bilski, software patent strategy

\section{INTRODUCTION}

The United States Patent and Trademark Office (USPTO) has been awarding patents on computer software for nearly 30 years. While software by definition is protected by copyright; ideas or new ways of doing business, which are sometimes embedded in software and require a machine to implement, are patentable. This category of patents is generally known as business method patents, but more often referred to simply as software patents.

The popularity of patenting software has never been greater, however, recent federal court rulings, strategy research, and the patent commons movement present organizations with a rather complex decision with regard to patenting their own software-based business methods. Of particular focus in the following discussion is the business method patent, which has been a popular yet somewhat controversial class of patents in recent years. We will first provide an overview of business method patents, and then discuss some of the challenges facing organizational decision makers with regard to the strategic pursuit of the patent for software based business methods.

\section{BUSINESS METHOD PATENTS}

Business method patents are relatively new. The United States Patent and Trademark Office (USPTO) created patent class 705 specifically for business method inventions in 1997. Class 705 is a collection of more than 20 financial and management data processing areas including, but not limited to, insurance, stock/bond trading, health care management, reservation systems, computerized postage meter systems and more general enterprise functions such as electronic shopping, auction systems, and business cryptography [USPTO, 2000]. Amazon.com's patent of the "1-click ordering system" is a well-known example of a software-based business method patent. Other familiar examples of business method patents include Priceline.com's patent for "name your price" reverse auctions and Doubleclick's patent for Internet advertising.

Business method patents are not awarded without proving the invention's merit. In the past, patent law required that four tests be met for a business method to be patentable:

1. The way of doing business must be useful;

2. It has to be new. The USPTO does not issue patents for old business methods simply converted to electronic form;

3. It cannot be so incremental that it would be obvious to a skilled practitioner; and

4. In the application process, disclosure of the innovation has to be so complete that fellow practitioners can understand it.

Since the late 1990's, the number of patent applications in class 705 has been rising dramatically. Because these patents are often based on software systems, they should be of particular interest to 
information systems scholars. A specific call for research has been made [Mykytyn, et al., 2002]; however, to date, only two empirical studies focused on business method patents have been identified in the IS literature [Boscaljon, et al., 2006; Martin and Mykytyn, 2009].

\section{LEGAL LANDSCAPE}

A number of court cases in the United States have shaped both the number of business method patent applications and USPTO approval of such patents. The State Street Bank \& Trust Co. v. Signature Financial Group, Inc. [1998] ruling helped broaden the scope of software patents and strengthened the patentability of software-based business methods [Lesavich, 2001]. Signature obtained a patent in 1993 on a software program that was used to determine the value of mutual funds. State Street Bank sued to have the patent invalidated on the grounds that it covered a business method and was hence not patentable. In the final appeal, the court rejected State Street's claim and Signature's patent was upheld. The decision specifically stated that software that governs business methods can be patented as long as it produces some concrete, useful, and tangible result [Ovans, 2000].

After the State Street Bank case the number of class 705 skyrocketed, but recent events may halt the ability for business methods, including softwarebased business methods, to be as easily patented in the future. A recent US Federal Circuit Court ruling [In re Bilski, 2008] involved Bernard Bilski and Rand Warsaw, who founded the company WeatherWise to sell computerized services based on their hedging method that is used by some utilities. The USPTO rejected the WeatherWise patent application in 2000; the USPTO Patent Board of Appeals upheld the rejection in 2006, and the Court of Appeals for the Federal Circuit upheld the decision in 2008. The denial was based on the interpretation that the claim involved a mental process, and did not require technology to implement.

There is uncertainty of the impact of the Bilski ruling on business method software patents. Some view decisions made by the USPTO in the post-Bilski era as leading to the elimination of many software and business process patents [Turner, 2009]. The Bilski ruling did not explicitly overrule the State Street ruling, but it did assert that the concrete, useful, tangible test is inadequate.

The Bilski case was appealed to the US Supreme Court. In late 2009 arguments were presented before the court, and a ruling will likely be issued in spring or summer 2010. Statements about the arguments before the court make it appear that the outlook for business method software patents is bleak. For example, The Wall Street Journal reported that during the arguments of In re Bilski "several justices seemed almost contemptuous toward businessmethod patents" [Bravin, 2009].

If the Bilski ruling is upheld by the US Supreme Court, it does not mean business method patents will be ineligible, but based on the Bilski ruling and comments from the US Supreme Court, it appears it may be nearly impossible for most business methods to pass the machine-or-transformation test, the basic test for all patent eligibility. This test requires that the claimed method either be tied to a particular machine or apparatus, or that it transform a particular article into a different state or thing. The greatest risk to business method patents is that the USPTO Board of Patent Appeals has already declared that a generalpurpose computer is not considered a particular machine for the purposes of patent eligibility. Therefore, software processes alone are unpatentable. This issue is likely to arise in future court decisions.

\section{PATENT STRATEGY}

The court rulings are important in that they may force significant change upon an organization's use of business method patents as part of its overall strategy. A patent is a desired form of intellectual property in that it provides legal protection of an innovation to the patent owner for a period of 20 years. Although there has been strong debate over the logic of awarding patents to both business methods and/or software, patents are used by some firms to obtain strategic advantages in negotiations, cross-licensing, blocking competitors, and preventing suits [Bessen and Hunt, 2007]. Firms also use business method patents as a defensive strategy or to show potential investors the legitimacy of an innovation [Meyer, 1992].

There are two studies that have attempted to provide an empirical connection between business method patent ownership and firm performance. Boscaljon et al. [2006] conducted an event study that examined the stock market reaction to the announcement of a firm being awarded a business method patent. The study found that "granting of a business method patent evokes a positive average stock price reaction." Martin and Mykytyn [2009] introduced one of the first empirical studies in the IS literature that examined business method patents and firm performance in terms of financial accounting 
measures. They found no relationship between patent ownership and firm performance when comparing firms that owned patents to their closest nonpatenting competitors. However, as with any strategy research, it is difficult to attribute firm performance to one competitive attribute (i.e. patent ownership).

In a world of analytics and key performance indicators, other metrics may need to be utilized to study firm performance impacts as a result of patenting business methods. Perhaps the relationship is not tangible. The number of licensing agreements and the amount of licensing income from patents could be indicators, but some firms choose not to license.

Other firms have held business method and other software-based patents but have shifted their patent strategy by joining the patent commons movement. In the spirit of the open source software movement, some patent holders have chosen to join the patent commons by publicly posting a document that makes a commitment to not enforce the patents they hold. Some of the companies that have made the commitment to not enforce their patents include IBM, Microsoft, Sun Microsystems, Oracle, HP, and Blackboard. The Patent Commons website explains:

Commitments provide legal protection for activities that might otherwise be considered infringement. By making a Commitment, a Contributor gives permission for others to engage in activities it could otherwise prevent, or for which the Contributor could collect damages or royalties. Courts have concluded it is unfair and inequitable for Contributors to encourage others to rely on their promise they will not enforce their patents and then sue them for infringement for doing so [http://www.patentcommons.org/].

Further analysis is necessary but unlikely to determine the true motives of patent commons firms. Some questions that should be addressed include: Are the patent commitments based on outdated software or methods? Are the released patents truly part of the firm's overall strategy or simply a public relations attempt at improving the firm's standing in the software development community? The critical consideration for organizations is that openness and sharing are yet another potential strategy that organizational decision-makers may choose to employ in place of or in conjunction with a patent strategy.

\section{IMPLICATIONS FOR ORGANIZATIONS}

Firms have acquired business method patents for a variety of reasons over the past two decades, but due to the more restrictive eligibility rules that will likely be applied in the future, firms will need to reassess the use of patenting for these strategies.

The uncertainty about how the Supreme Court may rule in the Bilski case leaves firm strategists in a quandary. At the center of the debate is the question of when is a business method patentable. It seems clear that when the method is tied to a specific machine, the test is passed. However, a general computer is not considered a machine, even when connected to the Internet. Many existing patents would fail this test. While the transformation facet of the test appears to be less volatile, if upheld, it too would seem to invalidate a number of existing patents.

Although In re Bilski dealt a blow to business method patents, it did not eliminate them completely. Without clear guidelines, the burden of support is on the patent applicant. For now, firms must reassess their reliance on the business method patent as part of the firm's strategy. As mentioned earlier, there are additional classes of software patents, which may be a possibility, and patent-less software or even opensource strategies are alternatives. One must keep in mind that even without a patent, software is still issued a copyright. Although it presents its own challenges with respect to piracy, a copyright is a form of protection for intellectual property that, unlike the business method patent, is likely to remain unchanged over time.

\section{REFERENCES}

1. Boscaljon, B., G. Filbeck, and T. Smaby (2006) "Information Content of Business Methods Patents", Financial Review, (41)3, pp. 387-404.

2. Bravin, K. and B. Kendall (2009) "Court Is Cool to Patents on Methods", The Wall Street Journal. November

10 , http://online.wsj.com/article/SB12577796616563 8699.html (current Dec. 1, 2009).

3. In re Bilski, 545 F.3d 943, 88 U.S.P.Q.2d 1385 (2008).

4. Bessen, J. and R.M. Hunt (2007) "An Empirical Look at Software Patents," Journal of Economics and Management Strategy, (16)1, pp. 157-89. 
5. Martin, N. and P. Mykytyn (2009) "Evaluating the Financial Performance of Business Method Patent Owners", Information Systems Management, (26)3, pp. 285-301

6. State Street Bank \& Trust Co. v. Signature Financial Group, Inc., 149 F.3d 1368 (Fed. Cir. 1998).

7. Toupin, James A, (2008). Practitioner Responsibilities: Should we rethink whether the duty of reasonable inquiry requires prior art searches? Presentation at the IPO 2008 Annual Meeting San Diego, CA, September 21-23, 2008. Retrieved on April 1, 2009 from http://www.bustpatents.com/toupin.pdf

8. Turner, James, (March 13, 2009). Has the US Patent System Gone Too Far? Christian Science Monitor. p. 25.

9. US Patent and Trademark Office. "708.02 Petition To Make Special [R-6] - 700 Examination of Applications", http://www.uspto.gov/web/offices/pac/mpep /documents/0700 708_02.htm (current Dec. 1, 2009).

10. Lesavich, S. (2001) "Are All Business Method Patents "One-Click" Away from Vulnerability?", Intellectual Property \& Technology Law Journal, (13)6, pp. 1-5.

11. Meyer, S.P. (1992) "Obtaining and Enforcing Patents for Software-Related Inventions: Avoiding the Pitfalls", Software Law Journal, (5), pp. 715-738.

12. Mykytyn, K., P. Mykytyn Jr., B. Bordoloi, and V. McKinney, and K. Bandyopadhyay (2002) "The Role of Software Patents in Sustaining IT-Enabled Competitive Advantage: A Call for Research", Journal of Strategic Information Systems, (11), pp. 5982.

13. Ovans, A. (2000) "Can You Patent Your Business Model?", Harvard Business Review, (78) p. 16. 